\title{
PENDIDIKAN BERBASIS ISLAM DAN MULTIKULTURAL DALAM KELUARGA SEBAGAI PEMBENTUK RELIGIUSITAS PADA ANAK
}

\author{
Musdalifah dachrud \\ musdalifahdachrud@iain-manado.ac.id \\ Yusra \\ E-mail: yusra@iain-manado.ac.id \\ Institut Agama Islam Negeri (IAIN) Manado
}

\begin{abstract}
This research is motivated by the fact that the role of families in forming religiosity in children is very influential for children's lives in the future, families, especially parents, are the first means for children to receive socialization. What children will become, parents are very influential, good and bad children in society are also influenced by parental education, especially in instilling Islamic education and multicultural education from an early age. Many people consider parents to be a reflection of children, so that religious and multicultural education given to children is expected to from good religiosity in children. Religiosity has an important role in human life and life, both personality and in groups. The low religiosity in children, illustrates that children still desperately need guidance from various parties, one of the most important is family.
\end{abstract}

Key Words : Islamic education, multicultural education, family, religiosity

\begin{abstract}
Abstrak. Penelitian ini dilatar belakangi oleh kenyataan bahwa peranan keluarga dalam membentuk religiusitas pada anak sangat berpengaruh bagi kehidupan anak di masa yang akan datang, keluarga terutama orang tua merupakan sarana pertama kali bagi anak dalam penerimaan sosialisasi. Anak akan menjadi apa kelak, orang tua sangatlah berpengaruh, baik buruknya anak dalam masyarakat juga dipengaruhi oleh didikan orang tua terutama dalam menanamkan pendidikan Islam dan pendidikan mulikultural sejak usia dini. Masyarakat banyak menganggap orang tua merupakan cerminan anak, sehingga pendidikan agama dan multikultural yang diberikan terhadap anak diharapkan dapat membentuk religiusitas pada anak dengan baik. Religiusitas memiliki peranan penting dalam hidup dan kehidupan manusia, baik secara pribadi maupun secara kelompok. Rendahnya religiusitas pada anak, menggambarkan bahwa anak masih sangat membutuhkan bimbingan dari berbagai pihak salah satunya yang terpenting adalah keluarga.
\end{abstract}

Kata Kunci : Pendidikan Islam, Pendidikan Multikultural, Keluarga, Religiusitas 


\section{Pendahuluan}

Pendidikan Islam merupakan usaha dan jalan yang di arahkan kepada pembentukan religiusitas pada anak sesuai dengan ajaran Islam. Pendidikan Islam sebagai wadah untuk membekali anak, agar mengenal keragaman yang dalam konteks ini dikenal dengan multikultural, yang sering kali memicu munculnya konflik sosial dan problem di antara umat manusia.

Pendidikan Islam dalam keluarga harus menempati posisi tertinggi dan utama yang harus di perhatikan orang tua terhadap anak-anaknya. Keluarga tempat anak pertama kali mengenal pendidikan agama. Keluarga merupakan unit sosial terkecil yang utama dan pertama bagi seorang anak. Sebelum ia berkenalan dengan dunia sekitarnya, seorang anak akan berkenalan terlebih dahulu dengan situasi keluarga. Pengalaman pergaulan dalam keluarga akan memberikan pengaruh yang sangat besar bagi perkembangan anak di masa yang akan datang. ${ }^{1}$

Menurut Soemanto (1989), yang dikutip Choiril Fuad Yusuf. Kehadiran anak dalam keluarga secara alamiah memberikan adanya rasa tanggung jawab dari pihak orang tua. Tanggung jawab ini didasarkan atas motivasi cintakasih yang pada hakekatnya juga dijiwai oleh tanggungjawab moral. Secara sadar, orang tua mengemban kewajiban untuk memelihara dan membina anaknya sampai ia mampu berdiri sendiri atau dewasa baik secara fisik, sosial, ekonomi maupun moral. Dengan demikian dapat diartikan, bahwa pendidikan dalam keluarga menjadi sangat penting. Hal ini disebabkan, oleh karena pendidikan dalam keluarga merupakan suatu

1 Ahmad Tafsir, Ilmu Pendidikan dalam Perspektif Islam (Bandung: Remaja Rosdakarya, 2001), h. 155 sarana untuk menghasilkan warga masyarakat yang besar dan baik. ${ }^{2}$

Untuk merealisasikannya dibutuhkan peran orang tua dalam membentuk religiusitas pada anak, yakni membekali mereka dengan pendidikan Islam dan pendidikan multikultural sejak usia dini, karena religiusitas terbentuk dan berkembang pada manusia sejak usia dini merupakan proses perpaduan antara potensi bawaan keagamaan dan pengaruh yang datang dari luar diri manusia itu sendiri. Dalam proses perkembangan tersebut akan terbentuk macam, sifat, serta kualitas religiusitas yang akan terekspresikan pada perilaku kehidupan sehari-hari.

Religiusitas yang dimiliki seseorang bukan hanya diwujudkan dalam bentuk ibadah ritual saja, melainkan aktivitas-aktivitas yang berhubungan dengan agama yang dianutnya dan mengarahkan bimbingan agar pribadi penganutnya menjadi baik dan terbiasa dengan yang baik menurut ajaran agamanya. Religiusitas juga berfungsi sebagai penyelamat manusia untuk kehidupan di dunia maupun di akhirat, serta dapat menjadi pengontrol perilaku seseorang dalam kehidupan sehari-hari agar memiliki rasa tanggung jawab. ${ }^{3}$

Pendidikan Islam dan pendidikan multikultural yang ditanamkan orang tua sangat berperan dalam pembentukan religiusitas pada anak. Pembentukan tersebut akan membawa anak dalam pertumbuhan dan perkembangan yang baik. Anak memerlukan pendidikan, pengawasan dan pemeliharaan yang terus menerus sebagai pelatihan dasar dalam

\footnotetext{
${ }^{2}$ Choirul Fuad Yusuf, Pendidikan Agama Bersama Kerukunan, (Jakarta: PT.Pena Citasatria, 2008), hh. 44-45

3 Jalaludin, Psikologi Agama, (Jakarta: Raja Grafindo Persada, 2002), hh. 247-249
} 
pembentukan kebiasaan dan sikap agar memiliki kumungkinan untuk berkembang secara wajar di kehidupan masa mendatang. ${ }^{4}$

Pendidikan anak pada dasarnya adalah kewajiban orang tua yang tidak dapat digantikan sepenuhnya oleh orang lain. Lingkungan keluarga adalah tempat pembentukan pendidikan maupun religiusitas. Karena pada dasarnya anak akan menyerap apa yang ada dalam lingkungan keluarganya. Maka dari itu, orang tua sangat berperan dalam membentuk religiusitas anak. Selain orang tua, dapat kita ketahui peranan lain yang dapat membantu berhasilnya peran orang tua dalam membentuk religiusitas anak lebih baik, seperti halnya pendidikan formal atau sekolah. Kerja sama dan penciptaan suasana yang kondusif antara pendidikan formal dan orang tua dalam membentuk religiusitas merupakan salah satu bentuk kemitraan yang perlu di pertahankan dan di kembangkan. ${ }^{5}$

$$
\text { Mengingat }
$$

pentingnya

Pendidikan berbasis Islam dan Mulitikultural dalam keluarga sangat berpengaruh dalam pembentukan religiusitas pada anak, oleh sebab itu penulis merasa tertarik untuk mengkaji sejauh mana pendidikan agama dan multikultural yang di berikan keluarga terhadap anak, sehingga bisa membentuk religuiusitas pada anak dengan baik.

Merujuk pada latar belakang pembahasan diatas, maka penulis merumuskan permasalahan sebagai berikut: 1) Bagaimanakah pendidikan berbasis Islam dan pendidikan Multikultural dalam keluarga? 2) Bagaimana peran orang tua dalam membentuk religiusitas pada anak

4 Jalaludin Rahmat, Psikologi Agama, (Jakarta: Raja Grapindo Persada, 1995), h. 204 Darmiyati Zuchdi, Humanisasi Pendidikan, (Jakarta: Bumi Aksara, 2009), h. 134 berbasis pendidikan Islam dan pendidikan multikultural 3) Apa saja faktor pendukung dan penghambat dalam membentuk religiusitas berbasis pendidikan Islam dan pendidikan multikultural pada anak?

\section{Pembahasan \\ Pendidikan Islam \\ Pengertian Pendidikan Islam}

Berbicara tentang pengertian pendidikan Islam, para ahli pendidikan Islam berbeda pendapat tentang asal kata pendidikan Islam. Dalam hal ini, ada tiga term yang berkaitan langsung dengan Pendidikan Islam, yakni tarbiyah, ta'dib, dan ta'lim. Secara singkat, istilah tarbiyah berasal dari akar kata rabb, yang dapat diartikan dengan tumbuh, berkembang, memelihara, merawat, mengatur dan menjaga kelestarian atas eksistensinya. ${ }^{6}$ Sedangkan istilah ta'lim berasal dari akar kata allama yang berarti mengajarkan. Istilah ta'dib sendiri berasal dari akar kata addaba yang berarti mendidik. Dari ketiga term tersebut, dapat kita pahami bahwa hakekat Pendidikan Islam adalah menjadikan manusia menjadi lebih baik. Baik itu melalui proses mengembangkan, merawat, mengatur, mendidik, mengajar dan sebagainya. Hal ini sangat wajar, mengingat islam diturunkan kedunia ini untuk di jadikan pedoman hidup manusia, supaya manusia selamat di dunia dan akherat. Sehingga untuk mampu merealisasikan tujuan tersebut, diperlukan seperangkat proses sistemik yang kemudian disebut pendidikan. $^{7}$

${ }^{6}$ Samsul Nizar, Filsafat Pendidikan Islam, (Jakarta: Ciputat Pers, 2002), h. 26.

${ }^{7}$ Ibid, h. 26 


\section{Hakekat Pendidikan Islam}

Hakekat pendidikan Islam menurut M. Arifin (1991:32) adalah "usaha orang dewasa muslim yang bertaqwa secara sadar mengarahkan dan membimbing pertumbuhan serta perkembangan fitrah (kemampuan dasar) anak didik melalui ajaran Islam ke arah titik maksimal pertumbuhan dan perkembangannya ${ }^{8}$. Sumber ajaran Islam adalah Al-Qur'an dan Hadits, maka pendidikan Islam pada hakekatnya tidak boleh lepas dari kedua sumber tersebut. Dalam Al-Qur'an dan Hadits, pendidikan lebih dikenal dengan istilah At-Tarbiyah.

\section{Tujuan Pendidikan Islam}

Komponen-komponen sifat dasar (tabiat) manusia yang diakui adalah tubuh, ruh dan akal. Tujuan pendidikan Islam secara umum dapat dibagi ke dalam tiga kelompok utama. Tujuan umum ini harus dibangun berdasarkan ketiga komponen ini yang masingmasingnya harus dipelihara sebaikbaiknya. Kegagalan dalam mencapai hasil memproduksi suatu pribadi akan menyebabkan hasilnya tidak kualified bagi peran khalifah. Sebagaimana penghancuran salah satu dari ketiga komponen ini akan menyebabkan hilangnya ketiga komponen pokok sebagai kesatuan yang utuh dan bulat, pandangan yang sama terjadi manakala tujuan pendidikan mengabaikan unsurunsur dasariah manusia. Ini berarti, bahwa kita di dalam pendidikan ini mempunyai tiga tujuan pokok, yakni tujuan jasmaniah (ahdaf al-jismiyyah), tujuan ruhani (ahdaf al- ruhiyyah) dan tujuan mental (ahdafal-'aqliyah). ${ }^{9}$

${ }^{8}$ M. Arifin, Ilmu Pendidikan Islam Suatu Tinjauan Teoritis Dan Praktis Berdasarkan Pendekatan Interdisipliner, (Jakarta: Bumi Aksara, 1991), h. 32

9 Abdurrahman Saleh Abdullah, Teoriteori Pendidikan berdasarkan Al-Qur'an, (Jakarta: Rineka Cipta, 1994), hh. 133- 145
Menurut Hery Nor Aly dan Mundir Suparta, tujuan Pendidikan Islam dibedakan menjadi dua, yakni tujuan umum dan tujuan khusus. Tujuan umum, Pendidian Islam adalah mendidik individu mukmin agar tunduk, bertaqwa dan beribadah dengan baik kepada Allah, sehingga memperoleh kebahagian di dunia dan akhirat. ${ }^{10}$

Sedangkan tujuan khusus dari pendidikan Islam adalah sebagai berikut.

a. Mendidik individu yang saleh dengan memperhatikan segenap dimensi perkembangannnya: rohani, emosional, sosial, inteklektual dan fisik.

b. Mendidik anggota sosial yang saleh, baik dalam keluarga maupun masyarakat muslim.

c. Mendidik manusia yang saleh bagi masyarakat yang besar.

\section{Kurikulum Pendidikan Islam}

Kurikulum merupakan landasan yang digunakan pendidik untuk membimbing peserta didik ke arah tujuan yang diinginkan melalui akumulasi sejumlah pengetahuan, keterampilan dan sikap mental.

Di sini kurikulum setidaknya mencakup empat hal, yaitu:

a. Tujuan pendidikan yang akan dicapai.

b. Isi pelajaran atau materi, yakni seperangkat pengetahuan, ilmu, data, aktivitas-aktivitas dan pengalaman yang menjadi sumber terbentuknya kurikulum.

c. Metode mengajar, yakni caracara mengajar dan bimbingan yang diikuti oleh murud-murid untuk mendorong mereka ke arah yang di kehendaki oleh tujuan.

${ }^{10}$ Hery Noer Aly dan Mundir Suparta, Watak Pendidikan Islam (Jakarta: Friska Agung Insani 2003), h. 143 
d. Metode penilaian, yakni cara untuk mengukur hasil dari proses pembelajaran. ${ }^{11}$

Karena kurikulum merupakan kerangka landasan dalam proses pembelajaran maka kurikulum harus dirumuskan sedemikian rupa, supaya tepat tujuan dan mampu berdialog dengan realitas peserta didik dan pendidik yang ada. Dalam kaitannya dengan hal ini kurikulum harus mempunyai asas atau prinsip, sebagai acuan garis besar terhadap perumusan kurikulum. Al-Syaibani menawarkan beberapa asas yang harus diperhatikan dalam kurikulum Pendidikan Islam, yaitu: asas agama, asas falsafah, asas psikologis dan asas sosial. ${ }^{12}$

\section{Pendidikan Multikultural Pengertian Pendidikan Multikultural}

Akar pendidikan multikultural, berasal dari perhatian seorang pakar pendidikan Amerika Serikat Prudence Crandall (18-3-1890) yang secara intensif menyebarkan pandangan tentang arti penting latar belakang peserta didik, baik ditinjau dari aspek budaya, etnis, dan agamanya. Pendidikan yang memperhatikan secara sungguh-sungguh latar belakang peserta didik merupakan cikal bakal bagi munculnya pendidikan multikultural. ${ }^{13}$

Secara etimologi istilah pendidikan multikultural terdiri dari dua term, yaitu pendidikan dan multikultural. Pendidikan berarti proses pengembangan sikap dan tata laku seseorang atau kelompok dalam usaha mendewasakan melalui pengajaran,

\footnotetext{
11 Hasan Langgulung, Azas-Azas Pendidikan Islam, (Jakarta: Pustaka Al-Husna, 1992)

12 Al-Syaibany, Falsafah Pendidikan Islam, (Jakarta: Bulan Bintang, 1979), h. 32.

13 Abudin Nata, Ilmu Pendidikan Islam Dengan Pendekatan Multidisipliner, (Jakarta: Raja Grafindo Persada, 2009), h. 21
}

pelatihan, proses dan cara mendidik. ${ }^{14}$ Multikultural diartikan sebagai keragaman kebudayaan, aneka kesopanan. ${ }^{15}$

Sedangkan secara terminologi, pendidikan multikultural berarti proses pengembangan seluruh potensi manusia yang menghargai pluralitas dan heterogenitasnya sebagai konsekuensi keragaman budaya, etnis, suku dan aliran (agama). ${ }^{16}$ Pengertian seperti ini mempunyai implikasi yang sangat luas dalam pendidikan, karena pendidikan dipahami sebagai proses tanpa akhir atau proses sepanjang hayat.

\section{Karakteristik multikultural \\ pendidikan}

Tiga karakteristik pendidikan multikultural menurut Abdullah Ali, yakni:

1. Berprinsip pada demokrasi, kesetaraan dan keadilan.

2. Berorientasi pada kemanusiaan, kebersamaan, dan kedamaian.

3. Mengembangkan sikap mengakui, menerima dan menghargai keragaman budaya. ${ }^{17}$

\section{Landasan Multikultural \\ Pendidikan}

Pendidikan Islam sebagai proses pembumian ajaran Islam agar umat dapat mengembangkan daya pikir, rasa dan tindakannya sesuai dengan ajaran Islam, maka upaya pengembangan pendidikan Islam tidak bisa dilepaskan dari landasan orbitnya yaitu Islam itu sendiri, apalagi aktivitas pendidikan

\footnotetext{
${ }^{14}$ Bukhari Umar, Ilmu Pendidikan Islam, (Jakarta: Amzah, 2010), h. 28

${ }^{15}$ Masgnud, Pendidikan Multikultural: Pemikiran dan Upaya Implementasinya, (Yogyakarta: Idea Press, 2010), h. 19

${ }^{16}$ Ibid, h. 21

17 Abdullah Ali, Pendidikan Islam Multikultural di Pesantren, (Yogyakarta: Pustaka Pelajar, 2011), h. 56.
} 
merupakan bagian tak terpisahkan dari ajaran agama. Oleh karena itu, peletakan landasan agama dalam pengembangan pendidikan Islam berbasis multikultural menjadi penting. Dalam perspektif agama, multikulturalisme sebagai basic dari pengembangan pendidikan multikultural, merupakan manifestasi Imani dalam merespon kehendak Allah Swt yang telah dengan sengaja menciptakan keberagaman dalam ciptaan-Nya dengan tanpa maksud menciptakan konflik, melainkan sebagai wahana untuk membangun sikap dan tindakan saling tolong menolong, atau saling melengkapi sehingga tercipta suatu kehidupan yang dinamis dan berkeseimbangan. ${ }^{18}$

\section{Tujuan}

Pendidikan

\section{Multikultural}

Pada dasarnya tujuan pendidikan multikultural selaras dengan tujuan pendidikan secara umum, yaitu mencetak peserta didik tidak hanya mampu mengembangkan potensi dirinya dalam penguasaan ilmu pengetahuan, seni dan teknologi, melainkan sekaligus mampu mengembangkan dan menerapkan nilainilai universal dalam kehidupan. ${ }^{19}$

\section{Multikulturalisme dalam}

\section{Pendidikan Islam}

Multikulturalisme adalah sebuah paham tentang realitas masyarakat yang beragam dan plural. Multikulturalisme merupakan sebuah respon dari sebuah

18 Multikulturalisme merupakan paham yang memandang bahwa pluralism merupakan keniscayaan, bukan hanya mengakui adanya kemajemukan melainkan memberi ruang sama terhadap keberagaman untuk berkembang. Lihat Ngainun Naim dan Ahmad Syauqi, Pendidikan Multikultural Konsep dan Aplikasi (Jogjakarta: Ar Ruzz Media, 2010), h. 126. Lihat juga Moh Yamin dan Vivi Aulia, Meretas Pendidikan Toleransi, Pluralisme dan Multikulturalisme Keniscayaan Peradaban (Malang: Madani Media, 2011), h. 22

M. Ainul Yaqin, Akademina Multikultural, (Yogyakarta: UIN Suku Press, tt), h. 14 fakta sosial yang beragam dan plural, sehingga keteraturan hidup yang humanis, demokratis dan berkeadilan akhirnya dapat di capai. ${ }^{20}$

Sejak awal, Islam turun ke dunia untuk tujuan kemanusiaan. Islam secara tegas dan jelas menyatakan bahwa Islam diturunkan untuk semesta alam (rahmatan lil'alamin). Artinya Islam lahir bukan semata-mata untuk umat Islam saja, tetapi semangat universalitas Islam sudah ditampakkan. Hal ini dapat kita lihat dari firman Allah tentang tujuan keterutusan Rasulullah, dan tujuan diturunkannya Islam, yang kemudian kita kenal dengan tujuan risalah.

Dalam Surat Al-Anbiya ayat 107, Allah berfirman yang artinya: "Dan tiadalah Kami mengutus kamu (Muhammad), melainkan untuk (menjadi) rahmat bagi semesta alam".21

Hal ini menegaskan betapa Islam diperuntukkan untuk semua manusia, bahkan semua alam dengan keragaman, perbedaan dan pluralitas yang mengitarinya. Pada dasarnya, Islam memandang multikulturalisme sebagai sebuah sunnatullah, keniscayaan alam yang tak terbantahkan. Perbedaan dan keragaman tersebut kemudian bukan menjadi alasan untuk saling berceraiberai, pecah-belah dan terjadi konflik. Dalam ayat lain dijelaskan bahwa keberagaman sosial umat manusia yang ada, tidak lain adalah untuk menguji manusia supaya mereka mampu berbuat baik dan menciptakan kedamaian. Sebagaimana yang termaktub dalam Surat Al-Maidah ayat 4:

"Untuk tiap-tiap umat diantara kamu, Kami berikan aturan dan

20 Muhamad Mustaqim dan Hikmatul Mustaghfiroh, Pendidikan Islam Berbasis Multikulturalisme, Jurnal Pendidikan Agama Islam, ADDIN Vol. 7 no.1 Februari 2013), h. 113114.

\footnotetext{
${ }^{21}$ Ibid, h. 115.
} 
jalan yang terang. Sekiranya Allah menghendaki, niscaya kamu dijadikan-Nya satu umat (saja), tetapi Allah hendak menguji kamu terhadap pemberianNya kepadamu, maka berlombalombalah berbuat kebajikan. Hanya kepada Allah-lah kembali kamu semuanya, lalu diberitahukan-Nya kepadamu apa yang telah kamu perselisihkan itu”.

Dalam ayat ini dapat kita pahami bahwa Allah sengaja menjadikan umat yang tidak satu, dengan tujuan untuk menguji manusia, bagaimana mereka memahami perbedaan dalam keragaman. Selain itu, supaya manusia mau berlomba lomba dalam kebaikan dan kebenaran, bukan untuk saling berselisih dan bercerai berai.

\section{Keluarga}

\section{Pengertian keluarga}

Keluarga adalah suatu institusi yang terbentuk karena adanya ikatan perkawinan antara sepasang suami istri yang mengikat janji untuk hidup bersama, dalam membangun keluarga sakinah, mawadah, warohmah dalam lindungan dan ridho Allah Swt. Keluarga adalah lembaga yang bersifat kodrati karena adanya hubungan darah antara pendidik dan anak didiknya, keluarga merupakan lembaga informal, yang tidak mempunyai program yang jelas dan resmi, selain itu keluarga juga merupakan lembaga yang bersifat kodrati, karena terdapatnya hubungan darah antara pendidik dan anak didiknya (Suwarno, 1992) 22

\section{dalam Keluarga}

\section{Dasar Pendidikan Agama}

Pendidikan agama dalam keluarga telah disyariatkan oleh Allah Swt dalam Al-Qur'an dan

${ }^{22}$ Mufatihatut Taubah, "Pendidikan Anak Dalam Keluarga Perspektif Islam” Jurnal Pendidikan Agama Islam, Vol. 3 no.1 Mei 2015, h. 4. diinterpretasikan melalui hadits Nabi Muhammad SAW, diantaranya;

QS. At-Tahrim: 6, terjemahnya:

"Hai orang-orang yang beriman, peliharalah dirimu dan keluargamu dari api neraka yang bahan bakarnya adalah manusia dan batu; penjaganya malaikatmalaikat yang kasar, keras, dan tidak mendurhakai Allah terhadap apa yang diperintahkan-Nya kepada mereka dan selalu mengerjakan apa yang diperintahkan."

QS. Al-Kahfi: 46, terjemahnya:

"Harta dan anak-anak adalah perhiasan kehidupan dunia tetapi amalan-amalan yang kekal lagi saleh adalah lebih baik pahalanya di sisi Tuhanmu serta lebih baik untuk menjadi harapan."

Rasulullah Saw bersabda:

$\begin{array}{lrr}\text { "Semua anak } & \text { dilahirkan } \\ \text { membawa } & \text { fitrah } & \text { (bakat } \\ \text { keagamagn) } & \text { maka terserah }\end{array}$

kepada kedua orang tuanya untuk menjadikannya beragama Yahudi, Nasrani atau Majusi" (HR.Muslim).

"Kewajiban orang tua kepada anaknya ialah memberi nama yang baik, mendidik sopan santun dan mengajari tulis menulis, renang, memanah, memberi makan dengan makanan yang baik serta mengawinkannya apabila ia telah mencapai dewasa" (HR.Muslim).

Dari beberapa keterangan diatas, baik Al-Qur'an dan Hadits mengisyaratkan bahwa pendidikan dalam keluarga sangat penting terutama dalam pendidikan agama. Pendidikan yang ditanamkan orang tua pada anak merupakan landasan dasar berpijak anak dalam berfikir dan berkembang secara jasmani, ruhani dan mental anak. 


\section{Pola Pendidikan Anak dalam Keluarga Perspektif Islam}

Pola atau metode merupakan suatu cara yang dilakukan oleh pendidik dalam menyampaikan nilai-nilai atau materi pendidikan pada peserta didik untuk menapai tujuan pendidikan.

Pola pendidikan agama dalam Islam pada dasarnya mencontoh pada perilaku Nabi Muhammad Saw dalam membina keluarga dan sahabatnya, karena segala perkataan dan perbuatan Rasulullah merupakan manifestasi dari kandungan Al-Qur'an. Metode yang di gunakan Rasulullah antara lain Metode Pendidikan Qur'ani. Metode pendidikan Qur'ani adalah metode yang berdasarkan pada kandungan Al-Qur'an dan As-Sunnah. Segala bentuk upaya pendidikan didasarkan kepada nilainilai Al-Qur'an dan As-Sunnah (Syahidin, 2005).

\section{Religiusitas}

Menurut Galzalba yang dikutip Gufron, "Religiusitas berasal dari kata religi dalam bahasa Latin "religio" yang akar katanya adalah religure yang berarti mengikat. Sehingga dapat disimpulkan bahwa religiusitas menunjuk pada tingkat keterikatan individu terhadap agamanya." 23

Sebagai makhluk ciptaan Allah, sebenarnya potensi agama sudah ada pada setiap manusia sejak ia dilahirkan. Potensi ini berupa dorongan untuk mengabdi kepada Sang Pencipta. Dalam terminology Islam, dorongan ini dikenal dengan hidayat al-Diniyyat (baca: hidayatud diniyah), berupa benih-benih religiusitas yang dianugerahkan Tuhan kepada manusia. Dengan adanya potensi bawaan ini manusia pada

${ }^{23}$ M. Nur Gufron dan Rini Risnawita S, Teori-teori Psikologi, (Jogjakarta: Ar-Ruzz Media, 2010), h. 169 hakikatnya
religiusitas. $^{24}$ adalah makhluk

\section{Metode Penelitian}

Penelitian ini menggunakan pendekatan kualitatif, untuk memperoleh data, peneliti menggunakan metode observasi, wawancara dan dokumentasi. Dengan menggunakan analisis reduksi data, penyajian data, penarikan kesimpulan/verifikasi. Penelitian ini juga melakukan keabsahan data dengan menggunakan teknik triangulasi.

\section{Hasil}

Hasil dari penelitian ini, menyimpulkan bahwa:

1. Pendidikan berbasis Islam dan pendidikan berbasis Multikultural dalam keluarga, merupakan pengajaran yang mendominasi di MI Al-Khairaat Mapanget, mata pelajaran agama yang diajarkan kepada anak-anak, mulai dari pembinaan akidah dan akhlak yang menjadi prioritas utama para guru, dan juga pendidikan multikulturalisme mengajarkan kepada peserta didik untuk saling menghargai perbedaan baik itu budaya, suku, etnis, bahasa bahkan agama. Di lingkungan keluarga terlebih orang tua sangat memperhatikan pendidikan berbasis Islam dan multikultural bagi anak-anak mereka.

2. Peran orang tua dalam membentuk religiusitas pada anak berbasis pendidikan Islam dan pendidikan multikultural: Orang tua sebagai pendidik pertama dan utana sejak anak lahir, sangat berperan penting dalam penanaman religiusitas pada anak.

24 Jalaluddin, Psikologi Agama, Memahamui Perilaku dengan Mengaplilasikan Prinsip-prinsip Psikologi, (Jakarta: Raja Grafindo Persada, 2012) h. 67 
Sejak lahir anak merupakan tanggung jawab orang tua terutama dalam menanamkan pendidikan menyangkut iman, tauhid, akhlak dan kepribadian serta pendidikan dalam hal beribadah.

Pendidikan multikultural memberikan pemahaman kepada anak bahwa manusia di ciptakan Tuhan dalam keragaman dan kemajemukan, sehingga manusia mampu melakukan sebuah interaksi antar keragaman tersebut yang tentunya akan sangat berpengaruh kepada pembentukan religiusitas pada anak. Pendidikan multikultural mengajarkan anak untuk bertoleransi, saling menghormati dan menghargai. Dari peran orang tua tersebut, maka terbentuk religiusitas anak yang semakin baik.

3. Faktor pendukung dan penghambat dalam membentuk religiusitas berbasis pendidikan Islam dan pendidikan multikultural pada anak:

Faktor pendukung meliputi keteladanan, motivasi, lingkungn, fasilitas yang diberikan orang tua. Faktor penghambat meliputi acara televise yang tayang saat jam sholat ataupun belajar, handphone atau Tablet yang bertujuan untuk bermain, serta Playstation atau game anak.

\section{Penutup}

1. Pendidikan berbasis Islam dan Multikultural dalam keluarga, merupakan hal yang utama dan prioritas yang di ajarkan di sekolah dan di lingkungan keluarga terlebih orang tua sangat memperhatikan pendidikan anakanak mereka/ orang tua memberikan perhatian yang serius dalam hal pendidikan berbasis Islam dan Multikultural.

2. Orang tua memegang peranan penting dan sangat berpengaruh terhadap pendidikan anakanaknya. Sebagai penanggung jawab anak, orang tua memiliki peran penting antara lain: memenuhi kebutuhan rohani berupa pembinaan anak untuk sholat, mendorong mengikuti kegiatan TPA, memberikan contoh dan membina anak agar memiliki akhlak yang baik dalam hal keagamaan.

Orang tua sebagai pendidik sangat berperan penting dalam penanaman religiusitas anak sejak usia dini. Sejak lahir di dunia anak merupakan tanggung jawab orang tua dalam menanamkan pendidikan menyangkut iman dan tauhid, akhlak dan kepribadian serta pendidikan dalam hal beribadah. Orang tua di harapkan mampu mengarahkan anakanaknya agar memiliki sikap saling menghargai terhadap semua orang, apapun latar belakangnya. Dari peran orang tua tersebut, maka terbentuk religiusitas anak yang semakin baik.

3. Faktor pendukung dalam membentuk relegiusitas pada anak meliputi: keteladanan, motivasi, lingkungn, fasilitas yang diberikan orang tua.

Faktor penghambat dalam membentuk relegiusitas pada anak meliputi: acara televise yang tayang saat jam sholat ataupun belajar, handphone atau Tablet yang bertujuan untuk bermain, serta Playstation atau game anak. 


\section{Daftar Pustaka}

Tafsir, Ahmad, Ilmu Pendidikan dalam Perspektif Islam, Bandung: Remaja Rosdakarya, 2001.

Yusuf, Choirul Fuad, Pendidikan Agama Bersama Kerukunan, Jakarta: PT.Pena Citasatria, 2008.

Jalaludin, Psikologi Agama, Jakarta: Raja Grafindo Persada, 2002.

Rahmat, Jalaludin, Psikologi Agama, Jakarta: Raja Grapindo Persada, 1995.

Zuchdi, Darmiyati, Humanisasi Pendidikan, Jakarta: Bumi Aksara, 2009.

Nizar, Samsul, Filsafat Pendidikan Islam, Jakarta: Ciputat Pers, 2002.

Arifin, M, Ilmu Pendidikan Islam Suatu Tinjauan Teoritis Dan Praktis Berdasarkan Pendekatan Interdisipliner, Jakarta: Bumi Aksara, 1991.

Abdullah, Abdurrahman Saleh, Teoriteori Pendidikan berdasarkan AlQur'an, Jakarta: Rineka Cipta, 1994.

Aly, Hery Noer dan Suparta, Mundir, Watak Pendidikan Islam, Jakarta: Friska Agung Insani 2003.

$\begin{array}{cr}\text { Langgulung, Hasan, } & \text { Azas-Azas } \\ \text { Pendidikan Islam, } & \text { Jakarta: } \\ \text { Pustaka Al-Husna, 1992. }\end{array}$

Al-Syaibany, Falsafah Pendidikan Islam, Jakarta: Bulan Bintang, 1979.
Nata, Abudin, Ilmu Pendidikan Islam Dengan Pendekatan Multidisipliner, Jakarta: Raja Grafindo Persada, 2009.

Umar, Bukhari, Ilmu Pendidikan Islam, Jakarta: Amzah, 2010.

Masgnud, Pendidikan Multikultural: Pemikiran dan Upaya Implementasinya, Yogyakarta: Idea Press, 2010.

Ali, Abdullah, Pendidikan Islam Multikultural di Pesantren, Yogyakarta: Pustaka Pelajar, 2011.

Yaqin, M. Ainul, Akademina Multikultural, Yogyakarta: UIN Suku Press, tt

Mustaqim, Muhamad dan Mustaghfiroh, Hikmatul, Pendidikan Islam Berbasis Multikulturalisme, Jurnal Pendidikan Agama Islam, ADDIN Vol. 7 no.1 Februari 2013.

Taubah, Mufatihatut, "Pendidikan Anak Dalam Keluarga Perspektif Islam" Jurnal Pendidikan Agama Islam, Vol. 3 no.1 Mei 2015.

Gufron, M. Nur dan Rini Risnawita S, Teori-teori Psikologi, Jogjakarta: Ar-Ruzz Media, 2010.

Jalaluddin, Psikologi Agama, Memahamui Perilaku dengan Mengaplilasikan Prinsip-prinsip Psikologi, Jakarta: Raja Grafindo Persada, 2012. 